\title{
Covid-19 Pandemic Partial Lockdown in Ghana and Its Implications on Livelihoods of Informal Workers in Affected Communities
}

\author{
John Amoah-Nuamah ${ }^{1 *} \quad$ Wahab Musah-Abdul ${ }^{2} \quad$ Lord Ebow Sampson ${ }^{3}$ \\ 1.Department of Geography and Regional Planning, University of Cape Coast, PMB, Cape Coat, Ghana \\ 2.Department of Planning, Kwame Nkrumah University of science and Technology, PMB KNUST, Kumasi, \\ Ghana \\ 3.Department of Geography and Regional Planning, University of Cape Coast, PMB, Cape Coat, Ghana \\ * E-mail of the corresponding author: nuamah12322@gmail.com
}

The research was financed by the authors

\section{Abstract}

Drawing on a review of literature, this study examined the livelihood of informal sector workers after partial closure of some urban centers in Ghana. We found that the livelihood situation of informal sector workers are likely to dwindle significantly due to the closure of major urban centers in Ghana. Policy makers need to institute measures to strengthen livelihood affected people in order for them to cope with the adverse effects on their livelihoods. Government and Non-governmental organization should help initiate effective policies and strategies that will enable informal workers as well as urban people have access to food and medical items needed at this crucial moment of their life.

Keywords: livelihoods, informal sector, COVID-19, partial lockdown and Ghana

DOI: $10.7176 / \mathrm{JESD} / 11-8-4$

Publication date: April $30^{\text {th }} 2020$

\section{Introduction}

Over the past months, the global communities have been confronted with an increasingly serious health menace from the new discovered virus called coronavirus (COVID-19) (Munster et al. 2020). The Coronavirus is a novel virus connected to the family of viruses as Severe Acute Respiratory Syndrome (SARS). According to European Centre for Disease Prevention and Control as at March $30^{\text {th }}, 2020$, a total of 715, 660 people had been confirmed infected, and 33,579 had died globally. They further revealed that, so far death cases reported from some of the leading countries are: Italy (10,781), Spain (6,528), China (3,311), Iran (2,640), France (2,606), United States $(2,509)$ and United Kingdom $(1,228)$. Even though the disease emanated from China, recent data shows that corona virus death cases and incidence for the month of February in countries like Spain and Italy have surpassed that of China which happen to be the epicenter of this novel and deadly virus. Despite the fact that the above mentioned counties are the leading countries as far as the epidemic is concerned, it is important to note that, the virus has spread to over 199 countries worldwide of which most of the cases are imported.

Aside the health implications of the pandemic, it also has socio-economic effects on the global communities. These other reasons have made the corona virus pandemic a very serious phenomenon. Most countries have closed down their borders and ports which suggests that international trade has halted which has affected international economies at large. The menace has not only affected international trade but also local trade since local communities have undergone some form of lockdown in response to halting the transmutability of virus through contact. The spread of COVID-19 pandemic around the world has caused global supply to dwindle leading to decreased business in the services sector. This has subsequently led to supply shortages since most people are compelled to engage in panic buying as well as increased utilization of certain goods to combat the pandemic in both developed and developing countries. For instance, there have been extensive news of shortage in supply of pharmaceutical products in most countries, especially in developing countries like Ghana. Although, most affected countries have put in place some timely interventions and control measures, notwithstanding the early and swift responses by the global communities on the increasing outbreak of the epidemic the rate of transmission is exponential.

According to WHO report, COVID -19 cases over the past weeks have increased exponentially and therefore swift precautionary measures must be employed to curtail the menace. This has necessitated most affected and non-affected countries to mount up critical hygienic, medical and social preventive and precautionary measure to curtail the situation. Some measures outlined by WHO on COVID-19 pandemic are: washing hands frequently with soap under running water and or using hand-sanitizing gel; maintaining social distancing (keeping a distance of 1 metre which is equivalent to 3 feet between two or more people and this applies to all persons who are coughing or sneezing); avoiding touching eyes, nose and mouth; following respiratory hygiene (covering your mouth and nose with your bent elbow or tissue when you cough or sneeze, then disposing of the used tissue 
immediately); seeking medical care early if you have a fever, cough and difficulty in breathing; and staying informed and following advice given by your health-care provider, national and local public health authority, or your employer on how to protect yourself and others from COVID-19 (WHO, 2019) .

Beside the above medical, hygienic and social measures outlined by the WHO, the COVID-19 pandemic continues to spread widely in most countries, especially in urban communities, this has necessitated implementation of more rigid and robust policies such as mandatory quarantine, fumigation exercise and partial and total lockdown of affected countries.

Ghana, is one of the leading countries in West Africa as far as the Coronavirus pandemic is concerned. On $12^{\text {th }}$ March, 2020 the Health Minister Kwaku Agyemang-Manu announced Ghana's first two cases at an emergency press briefing. Just after fifteen (15) days, thus on $27^{\text {th }}$ March 2020, Ghana confirmed a total of 137 cases. The exponential increase in the number of cases in Ghana made the President of Republic of Ghana to announce on Friday $27^{\text {th }}$ March, 2020 that restrictions on movement of persons in the Greater Accra Metropolitan Area (GAMA) and Greater Kumasi Metropolitan Area, for a period of two (2) weeks, subject to review. The motive behind the directive was to give the country opportunity to try to halt the spread of the virus, and scale-up effectively, contact tracing of persons who have come into contact with infected persons, test them for the virus, and if necessary, quarantine and isolate them for treatment, should they confirm to have the virus.

The partial lockdown of Greater Accra Metropolitan and Greater Kumasi Metropolitan areas is a good decision, however, majority of informal sector workers' livelihoods is largely dependent on these partially locked down urban communities. The implication is that majority of the informal sector workers have lost their employment that provided and sustained their livelihoods. The question then is; what will be the livelihood situation of informal sector workers in the partially locked down areas? However, it is important to note that conventional literature is silent on the likely effects of total and partial lock down of communities on urban informal workers. Therefore, this present study aims to address the gap in the conventional literature by assessing the effects of COVID-19 partial locked down on livelihoods in affected communities. Knowledge of the nature of livelihoods could inform the policies on the menace. Even though, the study is limited to Ghana, the results are likely to be significant for other countries in the globe where the COVID-19 has led to a partial or total lock down directive.

\section{Profile of the study areas}

The study covers two areas namely Greater Kumasi Metropolitan and Greater Accra Metropolitan areas. Figure 1 shows Kumasi Metropolitan in the national context while figure 2 shows Greater Accra Metropolitan area.

The Greater Accra Metropolitan area (GAMA) is located between latitude $5^{\circ} 5^{\prime} 27^{\prime \prime} \mathrm{N}$ to $5^{\circ} 28^{\prime} 2^{\prime \prime} \mathrm{N}$ and longitude $0^{\circ} 4^{\prime} 58^{\prime \prime}$ to the east and $0^{\circ} 37^{\prime} 2^{\prime \prime}$ to the west along the Atlantic coast of Ghana (See figure 1). The size of GAMA is approximately $1585 \mathrm{~km} 2$. The topography of the region varies from flat to gently undulating slopes that rise to $75 \mathrm{~m}$ at the foothills with a few isolated hills and rock outcrops.

Fig.1.Map of Greater Accra Metropolitan Area showing major towns Fig.2.Map of Greater Kumasi Metropolitan
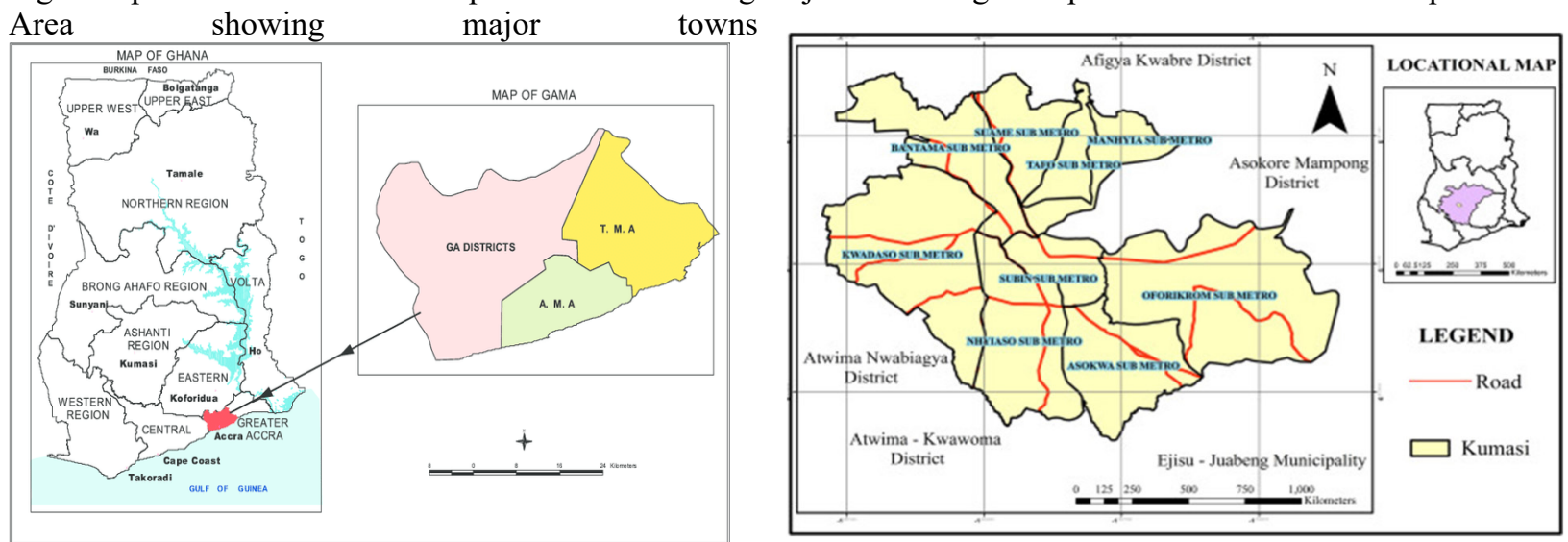

Source : (Oteng-ababio, 2014)

Source:(Amponsah et al, 2016)

The Greater Kumasi Metropolis is centrally located in the Ashanti Region of Ghana (See figure 2). It is located between Latitude $6^{\circ} .35^{\prime} \mathrm{N}$ and $6^{\circ} .40^{\prime} \mathrm{S}$ and Longitude $1^{\circ} .30^{\prime}$ Wand $1^{\circ} .35^{\prime} \mathrm{E}$ (GSS, 2014). It is the second largest city in Ghana and the administrative capital of Ashanti Region. It is a fast-growing Metropolis with an estimated population of more than two million people and an annual growth rate of about $5.4 \%$. It accommodates about $36.2 \%$ of the region's population with a population density of 8,013 persons/sq.km (Kumasi Metropolitan Assembly, 2017). 


\section{Livelihood}

Livelihood simply refers to the means of gaining a living. It is usually used interchangeably with income generating activities and employment, but the term livelihood goes beyond income generating activities by looking at more diverse and complex strategies of gaining a meaningful living (Chambers \& Conway, 1991). Haan and Zoomers (2003) explain livelihood as the ability of an individual, household and a group of people to meet their economic and social necessities as well as being able to cope with and maintain unforeseen circumstances.

The motivation of current studies on the means of livelihood of people stems from a paper by Gordon Conway and Robert Chambers in the year 1992. They were the first to coin a comprehensive and concise definition of livelihood. According to them livelihood is "the capabilities, assets (stores, resources, claims and access) and activities required for a means of living" (Chambers and Conway, 1992: 7). They acknowledge that the livelihoods of people are dependent on three main elements: capabilities, assets and activities. The ability for an individual or household to achieve their basic needs such as proper nourishment, good clothing, prevent avoidable disease and to feel a sense of belongingness is termed as capabilities (Kudzai and Emily, 2010). Activities are things people engage in to earn a living, for example farming, fishing. mining, teaching and so on are a major determinant of their livelihood. In this context, assets are the tangible and intangible resources available to the household, which provides their means of living and, is vital when considering the livelihood of people. Chambers and Conway definition of livelihood has been generally acknowledged by most international organizations and institutions as the operational definition of livelihood(Ashley \& Carney, 1999).

In Ellis' definition, he modified that of Chambers and Conway by explaining assets in terms of physical, social, financial, human and natural resources that are needed to achieve the basic necessities of life. Ellis also acknowledges the role of mediating institutions and social relations that shapes the living conditions of people. Government of Ghana issued directive through its institutions and organizations to ensure partial lock down in certain urban and peri-urban communities within the Greater Accra and Greater Kumasi metropolitan areas. Since these institutions and organizations play important role in transforming structures and processes that efficiently determine access to various types of capital, influence the livelihood strategies and put in place structures and processes to determine terms of exchange between different types of capitals (DFID, 2008). The decision is likely to have effects on the livelihood capital of informal sector workers in these restricted areas. This will ultimately have implications on the livelihood outcomes of vast number of informal workers whose livelihoods are highly dependent on these urban centers that have been partially locked down.

\subsection{Nature of Informal Sector workers livelihood}

The livelihoods of most urban workers in developing countries is dependent on the informal economy (Brown, Lyons, \& Dankoco, 2010; Lyons \& Snoxell, 2005; Williams \& Round, 2007). Consequently, understanding urban informal employment and income levels is critical to alleviating urban poverty. Nonetheless, most countries and cities around the globe are vigorously destroying urban informal livelihoods. Practices that exclude informal workers from participating in cities are the norm in many parts of the world: there are daily reports of slum and street vendor evictions and unreported harassment of informal workers by local authorities, including bribes and confiscation of goods, on a daily basis. The informal sector workers' livelihoods have numerous and distinguishing dynamics. Informal sector employment types and informal workers exist in both formal and informal economies (Chen, 2007; Cooke, 2008; Cooke, 2006). According to Anuwa-Armah, (2015) most (63.2\%) of informal sector workers are self-employed without employees and $29.5 \%$ are self-employed with employees. He further revealed that those with casual/ seasonal jobs constitute $3.7 \%$ and there are others who are self-employed with seasonal jobs and no employees $(2.2 \%)$; and employers who are self-employed with seasonal jobs but with employees $(1.4 \%)$. Whereas almost $70 \%$ of employers do not offer written short term or long term employment contracts $77.6 \%$ of employees, others do not have any employment contract at all or have only verbal contracts. As a result, in the event of a breach of their fundamental rights, workers are unable to exercise or defend them in court. Majority of employers (55.6\%) do not contribute to any pension scheme whilst $29.5 \%$ do. Akorsu \& Beale (2010) also asserted that informal sector workers can be classified into family members, apprentices, low level of organisation/little voice/bargaining power, paid casual workers, paid workers, poor terms and conditions. The unpublished report on the Mission of UNIDO official to National Board for Small Scale Industries, Accra, states that informal sector operators function from clusters, closer to cities, especially those engaged in auto repairs, metal works, but may also be strategically located at specific points to reach the maximum number of clients. In developing countries, kiosks and small containers owned by the informal sector operators litter every conceivable nook and cranny in the cities and towns (Barwa, 1995; Ofori, 2009). Many informal sector occupations from rickshaw drivers, street vendors, variety of repair service workers and waste pickers denote such job creation for earning a living income(Amin, 2016). The people employed in the informal sector are generally paid low salaries and wages due largely to the fact that there is excess labour supply and lack of skills that may attract higher wages. The entrepreneurs also get low return on their investment as a result of keen competition in that sector (Farrell et al, 2000; Ofori, 2009). 
Inadequate safety and health standards and environmental hazards are particularly evident in the case of the informal sector. Poor working environment including inadequate premises and often very unsatisfactory welfare facilities, as well as practically non-existent occupational health services are causing large human and material losses, which burden the productivity of national economies, impair health and general well-being as well as the quality of life of informal workers and their families. The protection of the health and welfare of informal sector workers is a challenge which should be faced with an integrated approach to health promotion, social protection and quality employment creation and has, therefore, to be part of a strategy to improve the basic living conditions of the urban poor.

According to Bertuzzo, (2016) informal sector workers usually live in settlement types such as slums physically decayed residential structures, squatters squat close to lakes, heels, privileged neighborhoods, railway station, airports; on marginal lands, low-lying public lands, embankments, footpath, overpasses and underpasses, etc. and shanty towns - poor quality dwellings and infrastructure - communities of the poor (Rempel, 1974).

\subsection{Implication of COVID-19 pandemic on employment of informal sector workers}

The livelihoods of a large number of urban dwellers in developing countries are hinged on the informal economy(Brown et al. 2010; Lyons \& Snoxell, 2005; Williams \& Round, 2007) .The informal sector accounts for a substantial percentage of the workforce in these countries, thus, its impact on GDP greatly surpasses that of the formal sectors of the economy when the value of output is taken into consideration (Ghana Statistical Service, 2016). Data from Ghana Statistical Service further shows that little above $86 \%$ of all jobs can be found in the informal economy with $90.9 \%$ of women and $81 \%$ of men working under circumstances which are to the largest extent not controlled, regulated or standardized by state institutions (Ghana Statistical Service, 2016). Majority of urban populace are absorbed by the informal sector in developing countries like Ghana (Debrah, 2007). Irrespective of the importance of the informal sector to the development of Ghana, the President of the Republic of Ghana announced on Friday 27th March, 2020 a partial lockdown in the Greater Accra Metropolitan Area (GAMA) and Greater Kumasi Metropolitan Area. Few days later most municipal and district capitals in Ghana were locked down. This is due to swift raising cases of COVID-19 pandemic in Ghana. Premising of the over reliance of the urban sectors economy and livelihoods on the informal sector and the partial lock down of urban areas which have ultimately led to close down of the informal sector, most informal sector workers who work as producers, wholesalers, retailers and consumers have lost their wage employment. The implication is that majority of urban informal sector workers such as rickshaw drivers, street vendors, variety of repair service workers and waste pickers are likely to be seasonally unemployed. What makes this issue more severe is that literature suggests that majority of the informal sector workers receives meager allowance and due to this, they are unable to make any meaningful savings for future uncertainties (Deberah, 2007; Kayitare, 2016). The phenomenon will put much burden on the informal sector workers as well as the government in the midst of the COVID-19 pandemic event.

\subsection{Implication of COVID-19 Pandemic on income of informal sector workers}

A lot of empirical studies indicate that the majority of informal workers have low incomes and live below or close to the poverty line (Hart, 2008; Tokman, 1978). However, absence of the informal sector, the magnitude of poverty would be much higher (Chidoko \& Makuyana, 2012; Hart, 2008).. Orlando, (2001) and Cartaya (1991) accentuates that a greater percentage of household income comes from the informal sector, both for poor and non-poor households in Venezuela. This situation is not different form that of Ghana. Moreover, Orlando (2001) further posited that the increase in the rate of informal earnings is lower than the increase in the rate on the number of workers in the sector. This means that the incidence of poverty is higher in the informal sector than in the formal sector. Therefore, he suggested that a strategy to reduce poverty should be to increase productivity and wage levels in the informal sector through improving education, experience, and capital access for informal employees. Similar study by Dhakal, (2010) also found that in most developing countries, the main reason why people are into the informal sector is to safeguard the poor and marginalized from poverty and unemployment. Dhakal, (2010) further accentuated that the informal sector is a good source of livelihood for poor and marginalized groups. He proved that earnings from the informal sector have been making a strong impact on the households' livelihood. Based on this, it is clear that the temporal closure and partial closure of the informal sector in Ghana is likely to have significant effects on income levels and poverty situations in Ghana.

\subsection{Implication of COVID-19 Pandemic on Health of informal sector workers}

The informal sector is characterized by poor safety and health precautions, standards and environmental hazards (Swuste \& Eijkemans, 2002). Thus, poor working environment including inadequate premises and often very unsatisfactory welfare facilities, as well as practically non-existent occupational health services are causing large human and material losses, which burden the productivity of national economies, impair health and general wellbeing as well as the quality of life of informal workers and their families. The protection of the health and welfare 
of informal sector workers is a challenge which should be faced with an integrated approach to health promotion, social protection and quality employment creation and has, therefore, to be part of a strategy to improve the basic living conditions of the urban poor. Premising on the above health conditions of the informal working environment, it's noteworthy that the closure of the informal sector will keep some of the informal workers for these unsafe working environments. This implies that health conditions of most informal sector workers is likely to improve. On the other hand, loss of job and income of most informal sector workers due to temporarily closure of the urban informal sector is likely to also impact negatively since evidence from literature suggests that the livelihoods of the most urban populace is dependent on the informal sector. Loss of daily income is likely to reduce the purchasing power of the informal sector workers as far as their health is concerned. In the nut shell, the COVID19 pandemic is likely to have both positive and negative effects on the health conditions of informal sector workers.

\subsection{The implications of COVID-19 Pandemic on Urban informal worker housing}

Majority of informal sector workers usually live in settlement types such as slums - physically decayed residential structures, squatters squat close to lakes, heels, privileged neighbor hoods, railway station, airports; on marginal lands, low-lying public lands, embankments, footpath, overpasses and underpasses, etc. (Bertuzzo, 2016) and shanty towns - poor quality dwellings and infrastructures - Communities of the poor (Rempel, 1974). Most dwellers of slums, squatters and shanty settlement pay on daily, weekly and monthly basis (Ghosh, 2008) and therefore partial closure of the informal sector due to the COVID-19 pandemic and temporal loss of wage employment means inability for most informal sector workers to pay their rent and ultimately leading to force ejection of most of the informal sector workers.

\subsection{The implications of COVID-19 Pandemic on Ghanaian Economy}

On the broader perspective, the informal sector is broadly considered as a major driver for local economic transformation in developing countries like Ghana (Haug, 2014; Ofori, 2009). The size of Ghana's informal sector is placed at 80 per cent of the total labour force (Hormeku, 1998). The large scale retrenchment of labour as overriding consequences of structural adjustment in Ghana in the mid-1980s, coupled with the inability to provide employment for the emerging labour force has created a large pool of unemployed persons who have naturally gravitated towards the informal sector. According to Nyamekye (2009), the size of the informal sector employment in the 1980s was twice that of the formal sector. However, by the $1990 \mathrm{~s}$, informal sector employment had increased by five and half $\left(5 \frac{1}{2}\right)$ times that of the formal sector (ibid). Growing informality is partly explained by low educational attainment. About 31 percent of Ghanaians aged 15 years and above have never attended school. A total of 55.7 percent of Ghanaians have attained only basic education and 13.6 percent have attained secondary education or higher. Generally, Ghanaian men have higher educational attainment than women (GSS 2008).

The inability of the formal private sector to generate jobs in their required quantities has also pushed many into the informal sector. As government continue to maintain a policy of net hiring freeze into the public sector and private sector firms fold up or switch to importation due to unfair competition from foreign companies, the formal sector continues to lose grounds in terms of its share of total employment. In the absence of appropriate social protection mechanisms (e.g. unemployment benefit) informal activities have become survival strategies for many Ghanaians; old and young.

Premising on the overarching benefits the informal sector provides to Ghana and other developing countries, the partial temporal closure of the urban areas due to the COVID-19 is likely to have enormous adverse effects on the local economies. This means that swift measures must be outlined to scale down the likely effects on the economy of Ghana and other developing countries at large.

\section{Conclusion}

The study explored the livelihood implications of partial lock down of urban centers on livelihood of informal sector workers of Ghana. The study revealed that majority of the urban populace in Ghana is highly dependent on the informal sector and therefore temporal closure of the sector is likely to have adverse effects on their livelihoods. The study further found out that the national economy is also highly hinged on the informal sector and so, temporal lock down will have significant effects on the national economy.

\section{Recommendations}

Premising on the findings that emerged from this study, we recommend that the government, management of Accra, Kumasi Metropolis and international organization should provide relief items such as rice, oil, tomatoes and fish to enable them improve livelihood situations of informal sector workers whose livelihoods have been affected by the COVID-19 pandemic. We again recommend that door to door free health services should be rendered to affected people to help salvage their situations. Government and other agencies should help create effective online platform for ordering food and medical items to enable informal workers as well as urban people have access to food and medical items needed at this crucial moment of their life. 


\section{Acknowledgements}

The author is extremely grateful to all those who participated in the study. But, I would like to express my special thanks to Mr. Timothy Chardoah-Nunoo and Mr. Ishmael Nanaba Acquah. Also, we owe a debt of gratitude to Dr. Owusu Amponsah - Senior Lecturer, KNUST Planning Department

\section{REFERENCES}

Akorsu, A. D., \& Beale, D. (2010). Labour standards application in Ghana: Influences, patterns and solutions (Doctoral dissertation, University of Manchester

Amin, A. N. (2016). The Informal Sector and. ReseachGate, 1-34.

Amponsah, O., Vigre, H., Braimah, I., Schou, T. W., \& Abaidoo, R. C. (2016). The policy implications of urban open space commercial vegetable farmers' willingness and ability to pay for reclaimed water for irrigation in Kumasi, Ghana. Heliyon, (2), 1-39. https://doi.org/10.1016/j.heliyon.2016.e00078

Anuwa-Armah, T. E. (2015). The Urban Informal Economy in Ghana: A Survey Report. Economic Development and Social Justice.

Ashley, C., \& Carney, D. (1999). Sustainable livelihoods: Lessons from early experience. Development, 64.

Brown, A., Lyons, M., \& Dankoco, I. (2010). Street Traders and the Emerging Spaces for Urban Voice and Citizenship in African Cities. Urban Studies, 47(March), 666-683. https://doi.org/10.1177/0042098009351187

Chambers, R., \& Conway, G. (1991). Sustainable rural livelihoods: practical concepts for the 21st century. IDS Discussion Paper, 296, 1-29. https://doi.org/ISBN 0903715589

Deberah, Y. A. (2007). The International Journal of Human Resource Promoting the informal sector as a source of gainful employment in developing countries : insights from Promoting the informal sector as a source of gainful employment in developing countries: insights from Gha. The International Journal of Human Resource Management, 18(6), 1063-1084. https://doi.org/10.1080/09585190701321716

DFID. (2008). DFID's Sustainable Livelihoods Approach and its Framework. Development, 1-5.

Dhakal, R. C. (2010). Impact of Informal Sector on Poverty and Employment in Nepal : A Micro- Level Study of Chitwan District Impact of Informal Sector on Poverty and Employment in Nepal : A Micro- Level Study of Chitwan District. The Economic Journal of Nepal, 33(2), 106-125.

Ghana Statistical Service. (2016). 2015 Labour Force Report. Accra.

Ghosh, A. K. (2008). Changing livelihood pattern of slum dwellers in Delhi : From a squatter settlement to a resettlement colony. Social Change, 38(3), 434-457.

Haan, L. E. O. D. E., \& Zoomers, A. (2003). Crossroads of Livelihood and Geographical Roots and, 94(3), 350362.

Hart, K. (2008). African Studies: Informal Income Opportunities and Urban Employment in Ghana Informal Income Opportunities and Urban Employment in Ghana. The Journal of Modern African Studies, 11(1), 6189. https://doi.org/10.1017/S0022278X00008089

Haug, J. (2014). Critical Overview of the (Urban) Informal Economy in Ghana. Accra.

Kayitare, E. (2016). Factors Affecting Rwandan Informal Sector Workers' Participation in Public Pension Schemes. Walden University.

Lyons, M., \& Snoxell, S. (2005). Creating Urban Social Capital : Some Evidence from Informal Traders in Nairobi. Urban Studies, 42(7), 1077-1097.

Ofori, G. E. (2009). TAXATION OF THE INFORMAL SECTOR IN GHANA : A CRITICAL EXAMINATION Kwame Nkrumah University of Science and Technology, Kumasi in partial fulfillment of the requirements for the degree of Commonwealth Executive Master of Business Administration INSTITUTE O. Kwame Nkrumah University of Science and Technology, Kumasi in.

Orlando, M. B. (2001). " The Informal Sector in Venezuela : Catalyst or Hindrance for Poverty Reduction ." Asociacion Civil Para La Promocion de Estudios Sociales, Poverty Project Papers, 2(1), 1-47.

Oteng-ababio, M. (2014). Waste Management \& Research. Waste Management \& Research, 28(4), $322-329$. https://doi.org/10.1177/0734242X09350247

Swuste, P., \& Eijkemans, G. (2002). Occupational Safety, Health , and Hygiene in the Urban Informal Sector of Sub-Saharan Africa: An Application of the Prevention and Control Exchange ( PACE ) Program to the Informal-sector Workers in Healthy City Projects Occupational Safety, Health , a. International Journal of Occupational and Environmental Health, 8(2), 113-118. https://doi.org/10.1179/107735202800338920

Tokman, V. E. (1978). An Exploration into the Nature of Informal - Formal Sector Relationships. THE URBAN INFORMAL SECTOR: Critical Perspectives on Employment and Housing Policies (Second Edition, Vol. 6). Pergamon Press Ltd. https://doi.org/10.1016/B978-0-08-024270-5.50007-7

Williams, C. C., \& Round, J. (2007). Re-thinking the Nature of the Informal Economy: Some Lessons from Ukraine. .. International Journal of Urban and Regional Research, 31(June). https://doi.org/10.1111/j.14682427.2007.00730.x 